\title{
Pemahaman Siswa pada Materi Fungsi Kuadrat dan Fungsi Rasional Berdasarkan Teori APOS ditinjau dari Gaya Kognitif Field Dependence dan Field Independence
}

\author{
Khairisti Iis Handayani ${ }^{1}$, Damris $\mathrm{M}^{2}$, Kamid $^{3}$ \\ 1, 2, 3 Program Studi Pendidikan Matematika, Universitas Jambi, \\ Jl. Raden Mataher No. 16-Jambi, Kota Jambi, Indonesia \\ Khairisti20@gmail.com
}

\begin{abstract}
Appropriate learning by considering students' cognitive styles can help students master learning materials. If students are able to master the learning material, it will help students to achieve mathematical abilities. One of the important mathematical skills is mathematical understanding. This study aims to determine students' understanding of quadratic functions and rational functions based on the APOS theory of students who have field dependence (FD) and field independence (FI) cognitive styles on the quadratic function and rational function material in class X MIIA1. This type of research was descriptive qualitative research. The research subjects consisted of 3 students with field dependence cognitive style and 3 students with field independence cognitive style. Data collection methods were tests and interviews. The instrument in the study was the researcher himself assisted by the GEFT test as an instrument for selecting prospective research subjects, a test of students' understanding of the quadratic function and racial function material, and interview guidelines. The data analysis technique in this study used Miles and Hubermen analysis. The results showed that students with the dependence field cognitive style were more likely to apply problem solving method not based on their thoughts, only accepting patterns that had been taught. Students with the field independence cognitive style tended to understand the types of questions and used internal factors.
\end{abstract}

Keywords: understanding, functions, APOS theory, Cognitive Style

\begin{abstract}
Abstrak
Pembelajaran yang tepat dengan mempertimbangkan gaya kognitif peserta didik dapat membantu peserta didik dalam menguasai materi pembelajaran. Apabila siswa mampu menguasai materi pembelajaran, maka membantu siswa dalam mencapai kemampuan matematik. Salah satu kemampuan matematik yang penting adalah pemahaman matematik. Penelitian ini bertujuan untuk menganalisis pemahaman siswa pada materi fungsi kuadrat dan fungsi rasional berdasarkan teori APOS pada siswa yang memiliki gaya kognitif field dependence (FD) dan field independence (FI) pada materi fungsi kuadrat dan fungsi rasional di kelas X MIIA1. Jenis penelitian ini adalah penelitian kualitatif deskriptif. Subyek penelitian terdiri dari 3 siswa dengan gaya kognitif field dependence dan 3 siswa dengan gaya kognitif field independence. Metode pengambilan data adalah tes dan wawancara. Instrument dalam penelitian adalah peneliti sendiri dibantu dengan tes GEFT sebagai instrumen pemilihan calon subjek penelitian, tes kemampuan pemahaman siswa pada materi fungsi kuadrat dan fungsi rasiaonal, dan pedoman wawancara. Teknik analisis data dalam penelitian ini menggunakan analisis Miles dan Hubermen. Hasil penelitian menunjukan bahwa siswa dengan gaya kognitif field dependence lebih cenderung mengaplikasikan metode penyelesaian soal tidak bersumber dari pikirannya, hanya menerima pola yang sudah diajarkan. Siswa dengan gaya kognitif field independence cenderung memaahami tipe-tipe soal dan menggunakan factor internal.
\end{abstract}

Kata kunci: Pemahaman, Fungsi, Teori APOS, Gaya Kognitif

Copyright (c) 2021 Khairisti Iis Handayani, Damris M, Kamid

$\triangle$ Corresponding author: Khairisti Iis handayani

Email Address: Khairisti20@gmail.com (Jl. Raden Mataher No. 16-Jambi, Kota Jambi, Indonesia)

Received 30 Mei 2021, Accepted 18 Juni 2021, Published 18 Juni 2021

\section{PENDAHULUAN}

Matematika merupakan ilmu universal yang berguna bagi kehidupan manusia dan juga mendasari perkembangan teknologi modern, serta mempunyai peran penting dalam berbagai disiplin ilmu dan memajukan daya pikir manusia (Suryopurnomo \& Pujiadi, 2017). Matematika dengan hakikatnya sebagai suatu kegiatan manusia melalui proses yang aktif, dinamis, dan generatif, serta sebagai pengetahuan yang 
terstruktur, mengembangkan sikap berpikir kritis, objektif, dan terbuka menjadi sangat penting untuk dimiliki peserta didik dalam menghadapi perkembangan iptek yang terus berkembang.

Matematika memuat suatu kumpulan konsep dan operasi hitung tetapi dalam pengajaran matematika pemahaman siswa mengenai hal tersebut lebih objektif daripada mengembangkan kemampuan dalam perhitungannya. Guru yang baik seharusnya mengajarkan pengetahuan dan keterampilan matematika serta mengumpulkannya dalam suatu komponen tersendiri. Guru hanya mengelompokkan matematika sesuai dengan buku teks. Hal itu menyebabkan semakin meluasnya konsep yang dipelajari oleh siswa (Hendriana \& Sumarmo, 2017).

Semakin meluasnya konsep yang dipelajari oleh siswa, maka seharusnya guru dapat membantu siswa dalam merekonstruksi konsep dan pengetahuan yang diperoleh. Guru memberikan kesempatan siswa untuk memahami konsep matematika berdasarkan gaya kognitif siswa. Gaya kognitif merupakan bagian dari gaya belajar yaitu sifat fisiologis, kognitif, dan afektif yang relatif tetap serta menggambarkan bagaimana peserta didik menerima, berinteraksi dan merespon lingkungan belajar (Desmita, 2014).

Guru perlu memiliki pengetahuan mengenai gaya kognitif agar dapat membantu guru dalam merancang atau memodifikasi materi, menentukan tujuan pembelajaran dan memilih strategi yang tepat dalam pembelajaran matematika. Dalam merancang pembelajaran matematika, guru yang memiliki perhatian pada gaya kognitif siswa akan menyajikan pembelajaran sesuai karakteristik dan potensi yang siswa miliki. Terdapat beberapa bentuk gaya kognitif yaitu gaya impulsif dan reflektif serta gaya field dependent dan field independent. Guru perlu memahami karakteristik masing-masing gaya kognitif sehingga pembelajaran matematika yang berlangsung dapat sesuai dengan proses dan perkembangan kognitif siswa (Desmita, 2014).

Gaya kognitif merupakan salah satu karakter siswa yang sangat penting dan berpengaruh terutama terhadap pencapaian prestasi belajar mereka. Gaya kognitif berkaitan dengan bagaimana mereka belajar melalui cara-cara sendiri yang melekat dan menjadi kekhasan pada masing-masing individu. Gaya kognitif sangat erat kaitannya dengan bagaimana cara menerima dan memproses segala informasi khususnya dalam pembelajaran (Darmono, 2012).

Pembelajaran yang tepat dengan mempertimbangkan gaya kognitif peserta didik dapat membantu peserta didik dalam menguasai materi ajar (Suriyah \& Noeruddin, 2019). Apabila siswa mampu menguasai materi ajar maka membantu siswa dalam mencapai kemampuan matematik. Salah satu kemampuan matematik yang penting adalah pemahaman matematik. Dalam pembelajaran matematika, pemahaman konsep sering diawali secara induktif melalui pengamatan pola atau fenomena, pengalaman peristiwa nyata atau intuisi. Proses induktif-deduktif dapat digunakan untuk mempelajari konsep matematika. Dengan demikian, cara belajar secara deduktif dan induktif digunakan dan sama-sama berperan penting dalam matematika. Dari cara kerja matematika tersebut diharapkan akan terbentuk sikap kritis, kreatif, jujur dan komunikatif pada peserta didik (Suryopurnomo \& Pujiadi, 2017).

Pemahaman konsep matematik merupakan bagian yang sangat penting dalam proses pembelajaran matematika (Nila, 2008). Pemahaman konsep matematik juga merupakan landasan penting untuk 
menyelesaikan persoalan-persoalan matematika maupun persoalan-persoalan dalam kehidupan sehari-hari. Namun kondisi dilapangan, menunjukkan banyak siswa yang belum memahami konsep dengan baik sehingga mereka kesulitan dalam menghubungkan konsep matematika yang sudah diperoleh dengan konsep yang baru diberikan.

Berdasarkan hasil observasi dan wawancara peneliti dengan salah satu guru matematika SMA Negeri 2 Sungai Penuh, menginformasikan bahwa siswa mengalami kesulitan dalam memahami materi fungsi. Siswa merasa kesulitan dalam memahami soal dan menjawab soal yang berkaitan dengan pemecahan masalah pada materi fungsi kuadrat dan rasional. Jika kondisi tersebut berlanjut, maka siswa akan menemukan kesulitan untuk materi-materi selanjutnya, karena disadari atau tidak materi pembelajaran matematika saling berkaitan. Kesalahan pada suatu konsep pengetahuan maka akan mengakibatkan kesalahan pengertian dasar hingga ke materi selanjutnya(Novitasari, 2016). Maka dari itu perlu ada solusi untuk mengatasi kesulitan siswa dalam memahami konsep fungsi kuadrat dan fungsi rasional.

Salah satu upaya yang dapat dilakukan guru adalah menganalisis gaya kognitif siswa agar guru dapat menentukan metode yang tepat. Metode pembelajaran yang tepat dapat meningkatkan kemampuan siswa dalam memahami konsep fungsi kuadrat dan fungsi rasional. Gaya kognitif yang dimiliki siswa dapat memberikan gambaran karakteristik siswa dalam belajar merekonstruksi konsep fungsi kuadrat dan rasional.

Teori APOS merupakan sebuah teori yang menggambarkan proses bagaimana konsep-konsep matematika dapat dipelajari, bagaimana seseorang individu itu membangun struktur mental pemahaman konsep dari apa yang dilihat dan baru dikenalinya sehingga dapat membangun sebuah konsep pengembangan pada permasalahan yang lebih kompleks(Gusman, Kamid, \& Syamsurizal, 2018). Pemahaman siswa pada konsep kuadrat dan fungsi rasional dapat dianalisis melalui analisis dekomposisi genetik sebagai operasionalisasi dari Teori APOS (Action, Processes, Object dan Schema). Teori APOS dapat digunakan untuk menganalisis pemahaman konsep siswa, salah satunya adalah konsep fungsi kuadrat dan fungsi rasional (Dubinsky \& Mcdonald, 2013).

Menurut (Khairani, 2008), Teori APOS dapat digunakan secara langsung dalam membandingkan keberhasilan atau kegagalan individu yang berkaitan dengan konstruksi mental yang telah terbentuk untuk suatu konsep matematika. Misalkan ada dua individu yang kelihatannya sama-sama menguasai suatu konsep matematika, Dengan teori APOS dapat dideteksi lebih lanjut siapa yang penguasaan konsep matematikanya lebih baik, yaitu jika seseorang dapat menjelaskan lebih lanjut konsep tersebut maka ia berada pada tingkat yang lebih baik daripada yang satunya.

Teori APOS akan membantu guru dalam meningkatkan pemahaman konsep fungsi kuadrat dan fungsi rasional. Melalui teori APOS, guru dapat melakukan analisis pemahaman konsep fungsi kuadrat dan rasional sehingga guru mengetahui tingkat pemahaman konsep siswa. Guru dapat melakukan perbaikan metode pembelajaran berdasarkan tingkat pemahaman fungsi kuadrat dan rasional tanpa melupakan gaya kognitif siswa. Berdasarkan penjabaran tersebut, peneliti tertarik untuk melakukan penelitian dengan judul 
"Pemahaman siswa pada materi fungsi kuadrat dan fungsi rasional berdasarkan teori APOS ditinjau dari gaya kognitif field dependent dan field indipendent".

\section{METODE}

Penelitian ini dilaksanakan di SMA Negeri 2 Sungai Penuh pada semester genap tahun ajaran 2020/2021. Penelitian ini termasuk jenis kualitatif deskriptif. Penelitian yang mengungkap jawaban terhadap fenomena atau pertanyaan melalui aplikasi prosedur ilmiah secara sistematis dengan menguatamakan kualitas data serta disajikan secara naratif(Strauss \& Corbin, 2003). Menurut Bogdan dan taylor penelitian kualitatif merupakan sebuah prosedur dasar penelitian yang menghasilkan data deskriptif berupa kata-kata tertulis atau lisan dari orang-orang dan perilaku yang diamati (Damapolii, 2014). Diharapkan melalui penelitian kualitatif deskriptif ini, peneliti dapat memahami fenomena tentang apa yang dialami oleh subjek peneliti yang disajikan dalam bentuk deskripsi kata-kata. Hal yang dideskripsikan dalam penelitian ini adalah kemampuan pemahaman siswa pada materi fungsi kuadrat dan fungsi rasioanal berdasarkan teori APOS ditinjau dari gaya kognitif field dependence dan field independence.

Data dalam penelitian ini berasal dari hasill tes perseptual Group Embedded Figures Test (GEFT) untuk menentukan gaya kognitif siswa. Instrumen Group Embedded Figures Test (GEFT) digunakan untuk mengukur gaya kognitif. Untuk mengukur dan mengelompokkan gaya kognitif field dependence dan field independence menggunakan Group Embedded Figures Test (GEFT) yang dicetuskan oleh Witkin. Ketentuan penilaian pada GEFT yaitu skor 1 untuk jawaban yang benar dan skor 0 untuk jawaban yang salah, dengan total skor yang diperoleh 0 sampai 18. Apabila skor yang diperoleh 10 smpai 18, maka subjek memiliki gaya kognitif field independence dan apabila skor yang diperoleh 0 smpai 9, maka subjek memiliki gaya kognitif field dependence dalam (Prihatiningsih \& Ratu, 2020). Hasil tes tertulis dan wawancara yang diolah sedemikian rupa sehingga akan diketahui gambaran kemampuan pemahaman siswa berdasarkan teori APOS pada materi fungsi kuadrat dan fungsi rasional.

Subjek yang dipilih pada penelitian ini adalah siswa kelas X MIIA 1 di SMA Negeri 2 Sungai Penuh sebanyak 19 siswa. Pemilihan kelas berdasarkan pada hasil pertimbangan nilai, guru mata pelajaran dan guru BK. Selanjutnya, proses pemilihan subjek dilakukan dengan diterapkannya kriteria pemilihan subjek. Kriteria tersebut adalah (1) siswa telah mendapatkan pembelajaran materi fungsi (2) siswa terpilih bergaya kognitif field dependence dan field independence (3) siswa dimungkinkan mampu mengkomunikasikan pemikirannya secara lisan maupun tulisan dengan baik.

Metode pengambilan data adalah tes tertulis dan wawancara. Instrument dalam penelitian adalah peneliti sendiri dibantu dengan tes Group Embedded Figures Test (GEFT) sebagai instrument pemilihan calon subjek penelitian, tes kemampuan pemahaman siswa pada materi fungsi kuadrat dan fungsi rasional, dan pedoman wawancara. Teknik pengumpulan data dalam penelitian ini dilakukan dengan teknik tes, teknik wawancara dan tekni studi dokumter. Soal kemampuan pemahaman pada materi fungsi kuadrat dan fungsi rasional digunakan adalah soal uraian dan terdapat dua soal. Soal kemampuan pemahaman pada materi fungsi berdasarkan teori APOS sebelumnya diujikan terlebih pada ahli materi. Dalam penelitian ini 
divalidasi oleh dosen matematika. Teknik analisis data dalam penelitian ini menggunakan analisis Miles dan Hubermen yang meliputi reduksi data, penyajian data dan penarikan kesimpulan (Sugiyono, 2020).

\section{HASIL DAN DISKUSI}

Peneliti memberikan tes gaya kognitif siswa dengan menggunakan instrument Group Embedded Figures Test (GEFT) yang dilaksanakan pada Rabu, tanggal 13 Januari 2021 pada pukul 08.45 WIB pada jam mata pelajaran matematika. Berdasarkan tes gaya kognitif siswa dengan menggunakan instrument Group Embedded Figures Test (GEFT) berikut persentase keseluruhan hasil tes GEFT:

Table 1 Persentase Perolehan Hasil Tes GEFT

\begin{tabular}{|c|c|c|}
\hline GayaKognitif & Frekuensi & Persentase \\
\hline field dependence (FD) & 12 & $63,2 \%$ \\
\hline field independence (FI) & 7 & $36,8 \%$ \\
\hline Total & 19 & $100 \%$ \\
\hline
\end{tabular}

Berdasarkan kriteria yang dipaparkan pada metode dipilih 6 siswa sebagai subjek, adapun inisial subjek dalam penelitian yaitu:

SFD1 = Subjek Field Dependence 1

SFD2 $=$ Subjek Field Dependence 2

SFD3 = Subjek Field Dependence 3

SFI1 = Subjek Field Independence 1

SFI2 $=$ Subjek Field Independence 2

$\mathrm{SFI} 3=$ Subjek Field Independence 3

Analisis data dan pembahasan tertulis dan wawancara subjek.

1. Subjek Field Dependence

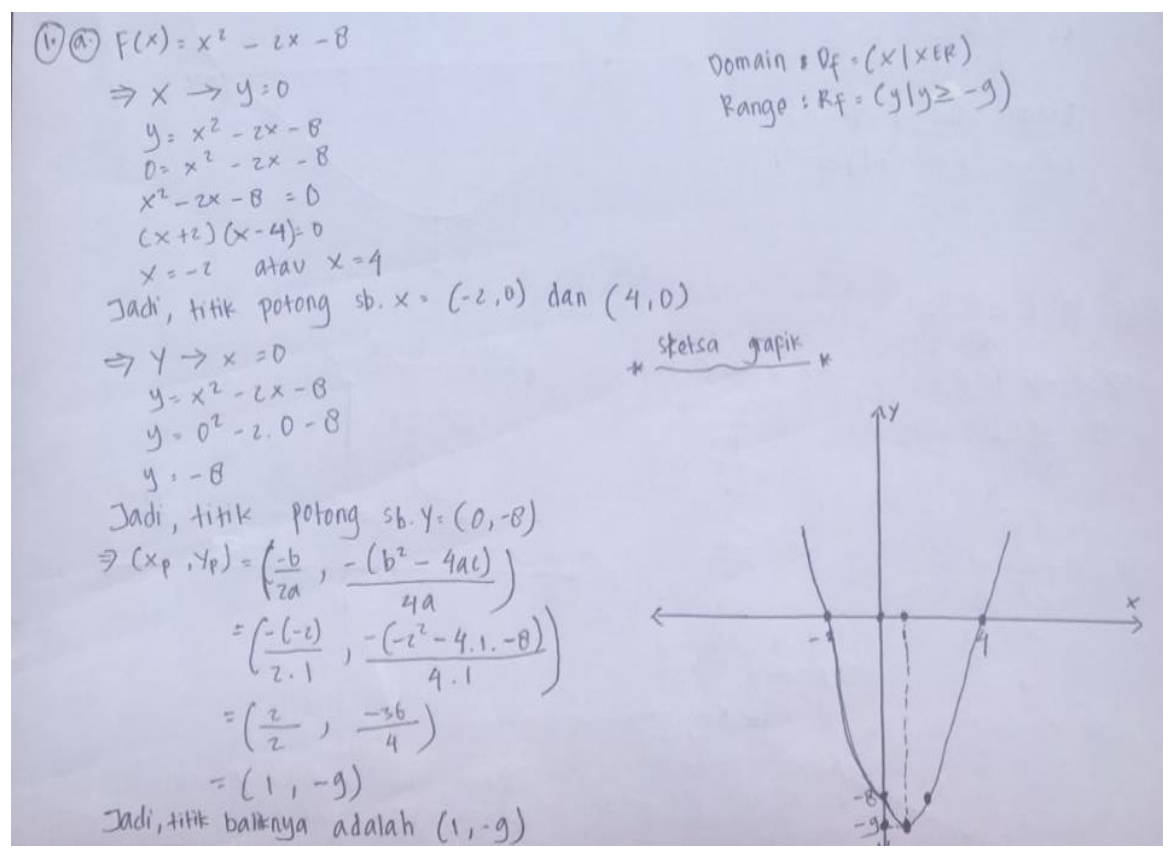

Gambar 1 Hasil tes SFD1 
Gambar 1 merupakan jawaban tertulis SFD1 terlihat bahwa subjek sudah memenuhi maksud soal sehingga dapat menjawab dengan menggunakan konsep. Namun subjek belum mampu menggunakan pemahaman berdasarkan pada satu konsep fungsi. Ketika ditanya seputar jawaban subjek tidak dapat memperhitungkan alasan-alasan yang bersumber dari pikirannya. Hal ini mengidentifikasi bahwa dalam menggambar grafik dan menentukan domain dan range subjek cenderung menduga berdasarkan dari pengalaman sebelumnya. Subjek masih sebatas melakukan intruksi secara eksplisi, secara keseluruhan subjek berada pada tahap proses. Terlihat pada gambar 2 subjek FD2 tidak menyelesaikan jawabannya.

Subjek FD2 kurang mampu menjelaskan hasil jawabannya dengan baik meskipun mampu menginterioritaskan konsep dasar dengan baik. Meskipun subjek mampu menerapkan rumus atau langsung menggunakan rumus fungsi kuadrat dan fungsi rasional secara perhitungan aljabar .SDF2 mampu memanipulasi namun belum menggunakan metode menyelesaikan soal dengantepat. Subjek belum menunjukkan pemahaman secara konseptual. SFD2 belum dapat menyelesaikan soal dengan langkahlangkah yang berdasarkan pada suatu konsep fungsi kuadrat dan fungsi rasional. Berdasarkan data wawancara subjek belum dapat menjelaskan bukti alasan secara menyakinkan. Sehingga pemahaman subjek masih berada pada tahap aksi.

Subjek FD3 menerapkan rumus dan langsung menggunakan rumus yang berkaitan dengan menggambar grafik fungsi kuadart dan fungsi rasional. Pada tahap perhitungan aljabar secara empiric subjek belum mampu menyelesaikan dengan tepat secara procedural. Berdasarkan data wawancara subjek belum mampu menjelaskan seputar strategi dalam memperoleh jawaban. SFD3 cenderung menduga berdasarkan pengalamannya, sehingga hanya memeberi alasan berdasarkan kata-kata dari guru (meniru pola). SFD3 belum menunjukkan pemahaman secara konseptual sehingga pemahaman subjek masih berada pada tahap aksi.

\section{Subjek Field Independence}

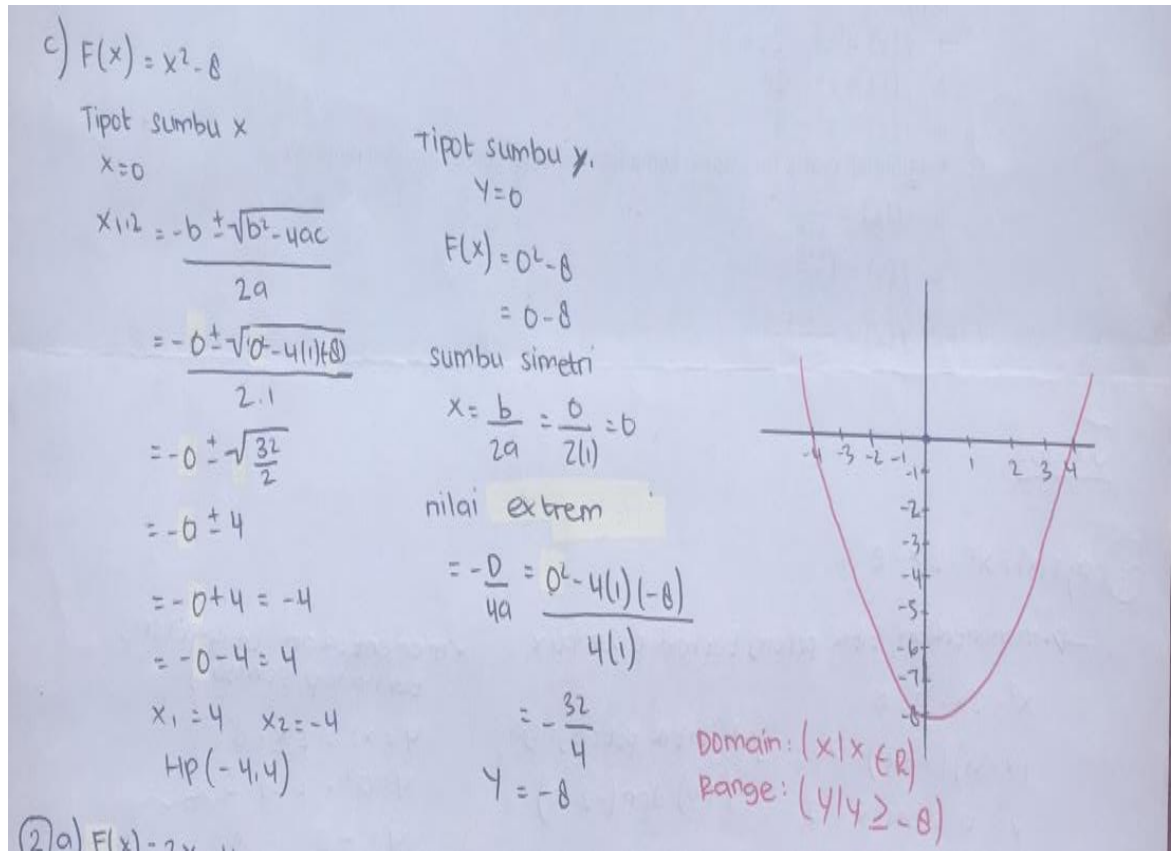

Gambar 2 Hasil tes SFI1 
Gambar jawaban tertulis terlihat bahwa SFI1 mampu menerapkan rumus dan langsung menggunakan rumus dalam menyelesaikan soal. Subjek mampu melakukan perhitungan aljabar secara empiric dan subjek mampu memanipulasi dan mengunakan metode yang tepat dalam menyelesaikan soal. SFI1 dapat menyelesaikan soal dengan langkah-langkah yang berdasarkan pada suatu konsep fungsi dengan definisi, sifat-sifat dan aturanyang berlaku pada fungsi kuadrat dan fungsi rasional. Subjek FI1 mampu mengunakan aturan yang berlaku dan mengunakan keterkaitan konsep pada materi fungsi kuadrat dan fungsi rasional dan materi lain untuk menyelesaikan soal. Berdasarkan data wawancara SFI1 mampu menjelaskan bukti alasannya dalam menyelesaikan soal dan memahami materi fungsi kuadrat dan fungsi rasional.

SFI2 mampu menerapkan rumus dan menggunakan rumus dalam menyelesaikan atau menggambar garfik fungsi kuadrat dan fungsi rasional. Pada perhitungan aljabar secara empiric subjek sudah mampu menerapkan. Subjek mampu memanipulasi dan mengunakan metode yang tepat dalam menyelesaikan soal dan subjek memiliki pemahan procedural dalam menyelesaikan soal. Subjek dapat menyelesaikan soal dengan langkah-langkah yang berdasarkan aturan-aturan dalam menggambar grafik fungsi kuadrat maupun aturan-aturan dalam menggambar grafik fungsi rasional. Hal ini terlihat pada subjek menggunakan rumus untuk menentukan asimtot tegak dan asimtot mendatar suatu fungsi. Subjek mampu menggunakan keterkaitan konsep pada soal fungsi kuadrat dan fungsi rasional untuk menyelesaikan soal. Berdasaran data wawancara secara keseluruhan subjek FI2 dapat menjelaskan bukti alasan menyelesaikan soal seperti menjelaskan domain fungsi dan range fungsi dengan notasi matematika yang tepat dan pemahaman SFI2 pada tahap skema.

SFI3 mampu menerapkan rumus dalam menyelasaikan soal menentukan grafik fungsi kuadart dan fungsi rasional. SFI3 mampu memanipulasi dengunakan metode yang tepat dalam menyesaikan soal. Walaupun dalam melakukan perhitungan aljabar subjek belum mampu karena terdapat kekeliruan operasi pehitungan. Dan subjek mengabaikan aturan penilisan notasi matematika dalam menerapkan rumus. Subjek dapat menyelesaikan soal dengan langkah-langkah yang berdasarkan pada suatu konsep fungsi aturan yang berlaku pada fungsi kuadrat dan fungsi rasional. SFI3 belum mampu menjelaskan ketrkaitan konsep penerapan definisi, sifat-sifat atau aturan yang berlaku pada fungsi kuadrat dan fungsi rasional untuk menyelesaikan soal.

\section{Diskusi}

Berdasarkan hasil penelitian pada lembar kemampuan pemahaman, untuk nomor-nomor tertentu ternyata ada kriteria dari APOS yang tidak dipenuhi oleh siswa gaya kognitif field dependence misalnya pada soal nomor 1a hanya mencapai tahap proses, sedangkan pada soal nomor 2 hanya mencapai tahap aksi. Sedangkan kriteria dari teori APOS yang tidak dipenuhi oleh siswa gaya kognitif field independence misalnya pada soal nomor 1a hanya mencapai tahap objek, dan soal nomor 2 hanya mencapai tahap proses.

Secara umum persepsi gaya kognitif field dependence mudah terpengaruh dan kurang mampu memberikan penguatan yang didefinisikan secara jelas sedangkan persepsi gaya kognitif field independence cenderung tidak mudah terpengaruh dan mampu memberi penguatan yang didefinisikan secara jelas. Gaya kognitif yang digunakan oleh siswa field dependence dan field independence dalam menyelesaikan soal 
fungsi kuadrat dan fungsi rasional cenderung berbeda, siswa gaya kognitif field independence lebih analitis alur berpikirnya daripada siswa gaya kognitif field dependence. Sedangkan dari analisis dan deskripsi data dapat dilihat bahwa antara subjek field independence dan field dependence dalam menyelesaikan soal terdapat suatu perbedaan, walaupun perbedaan ini tak selamanya dimaknai selalu menghasilkan sebuah jawaban benar. Hal ini sebagiamana teori yang mengatakan bahwa individu yang memiliki gaya kognitif berbeda, kecendrungan perbedaan kemampuan yang dimiliki lebih besar. Karakteristik gaya kognitif field independent umumnya dominan condong kepada independent, kompetitif, dan percaya diri. Sedangkan individu dengan field dependent lebih condong bersosialisasi, menyatukan diri dengan orang-orang di sekitar mereka, dan biasanya lebih berempati dan memahami perasaan dan pemikiran orang lain (Suriyah \& Noeruddin, 2019).

Tabel 2 Pemahaman Siswa pada Materi Fungsi Kuadrat dan Fungsi Rasional

\begin{tabular}{|c|c|c|c|c|c|c|}
\hline \multirow{2}{*}{ Subjek } & \multicolumn{7}{|c|}{ Pemahanan Subjek } \\
\cline { 2 - 7 } & $1 \mathrm{a}$ & $1 \mathrm{~b}$ & $1 \mathrm{c}$ & $2 \mathrm{a}$ & $2 \mathrm{~b}$ & $2 \mathrm{c}$ \\
\hline SFD1 & $\mathrm{P}$ & $\mathrm{A}$ & $\mathrm{O}$ & $\mathrm{P}$ & $\mathrm{O}$ & $\mathrm{A}$ \\
\hline SFD2 & $\mathrm{O}$ & $\mathrm{A}$ & $\mathrm{A}$ & $\mathrm{S}$ & $\mathrm{O}$ & $\mathrm{A}$ \\
\hline SFD3 & $\mathrm{O}$ & $\mathrm{S}$ & $\mathrm{A}$ & $\mathrm{S}$ & $\mathrm{O}$ & $\mathrm{A}$ \\
\hline SFI1 & $\mathrm{S}$ & $\mathrm{S}$ & $\mathrm{S}$ & $\mathrm{S}$ & $\mathrm{O}$ & $\mathrm{O}$ \\
\hline SFI2 & $\mathrm{S}$ & $\mathrm{O}$ & $\mathrm{S}$ & $\mathrm{S}$ & $\mathrm{O}$ & $\mathrm{S}$ \\
\hline SFI3 & $\mathrm{O}$ & $\mathrm{S}$ & $\mathrm{S}$ & $\mathrm{S}$ & $\mathrm{S}$ & $\mathrm{O}$ \\
\hline
\end{tabular}

Keterangan: A: Aksi P: Proses O: Objek $\quad$ S: Skema

Berdasarkan hasil penelitian diwakili oleh 3 subjek penelitian pada subjek gaya kognitif field dependence yaiti SFD1, SFD2, DAN SFD3 terlihat bahwa gaya kognitif yang digunakan dalam menyelesaikan soal tentang fungsi kuadrat dan fungsi rasional langkah awalnya adalah melihat tipe soal kemudian mempersepsi metode sesuai dengan pengalaman yang pernah ditemui. Subjek field dependence mempersepsi metode sesuai dengan bentuk soal yang pernah ditemui, mereka pun cenderung mengalami kesulitan fakta dikarenakan melakukan dalam salah menggunakan fungsi dari symbol tambah (+), kurang $(-)$, bagi $(\div)$, kali $(\times)$. Subjek gaya kognitif field dependence mempersepsi metode pengerjaan sesuai dengan bentuk soal yang pernah ditemui, mereka juga cenderung mengaplikasikan metode tersebut tidak bersumber dari pikirannya, hanya menerima yang sudah diajarkan oleh guru.

subjek field dependence tidak dapat membuat kesimpulan valid dari informasi-informasi yang telah diketahui dalam soal untuk memperoleh hal yang ditanyakan. Mislanya nomor 2, subjek field dependence mengetaui bahwa grafik fungsi rasional memiliki syarat mencari asimtot tegak/asimtot mendatar tetapi SFD tidak mancari titik sumbu $x$ dan sumbu $y$ terlebih dahulu. Dalam menggambar grafik subjek belum memiliki alur pemprosesan yang terstruktur. Dimana subjek field dependence tidak memcoba menfaktorkan kemudian mensubstritusi nilai $x=0$ ke fungsi terlebih dahulu. Subjek field dependence tersebut mampu menghasilkan jawaban yang tepat tetapi belum mampu memutuskan jawaban benar tersebut menggunakan 
aturan (teoritis). Dari kecenderungan tersebut menunjukkan bahwa subjek dengan gaya kognitif field dependence ada kecenderungan memandang permasalahan secara menyeluruh. Pemahaman mereka masih berada pada tahap aksi, subjek yang berada pada tahap aksi ini umumnya masih belum dapat menerapkan konsep atau prinsip matematika dalam pikirany. Hal ini sesuai dengan teori bahwa individu gaya kognitif field dependence menenrima suatu pola sebagai suatu keseluruhan. Mereka sulit untuk menfokuskan pada satu aspek dari satu situasi, atau menganalisis pola menjadi bagian-bagian yang berbeda (Desmita, 2014).

Menurut Eisenhart (Muryono,2008) pengetahuan procedural dan pengetahuan konseptual merupakan aspek penting dalam pemahaman matematika dan untuk memahami matematika harus menerapkan kedua pengetahuan tersebut. Maka pada tahap aksi siswa dianggap masih sebatas melakukan aktifitas procedural dan belum memiliki pengetahuan procedural apalagi pengetahuan konseptual, siswa mengerjakan tanpa memiliki kesadaran dalam melaksanakan tiap-tiap langkah dari proses jawabannya. Akibatnya, siswa cenderung menggunakan pengetahuan proseduralnya ketika dihadapkan dengan suatu permasalahan. Padahal jenis pemahaman ini hanya mendorong kemampuan mengingat semata, dan siswa yang berhasil dala hal ini adalah siswa yang dapat mengingat secara detail prosedur-prosedur dalam urutan yang benar. Kecenderungan ini membawa dampak bila urutan soal diubah atau dimodifikasi, siswa akan mengalami kegagalan menyelesaikannya (Kusaeri, 2015).

Menanamkan pemahanan yang bertumpu pada pengetahuan procedural yang dikuatkan dengan pengetahuan konseptual, siswa diharapkan mampu menerapkan pengetahuannya tersebut pada situasi permasalahan yang berbeda-beda karena menurut (Hudojo,2012) bahwa mempelajari suatu materi matematika yang baru, seseorang akan lebih mudah mempelajarinya jika itu didasari kepada apa yang telah diketahuinya.

Sedangkan untuk subjek gaya kognitif field independence, dari hasil penelitian yang diwakili oleh 3 subjek penelitian yaitu SFI1, SFI2, dan SFI3 terlihat bahwa gaya kognitif yang digunakan SFI dalam menyelesaikan soal tentang fungsi kuadrat dan fungsi rasional pertama kali yaitu memahami tipe-tipe soal berdasarkan pemikiran sendiri kemudian melakukan penyelesaian. Sehingga, mereka memiliki alasan yang menggunakan pemikiran matematis terhadap penyelesaiannya.

Subjek field independence dapat memperluas pemikiran matematis dengan menegaskan kembali cara yang lebih umum dan lebih luas. Hal ini sejalan dengan yang dikemukakan Goodenough (Vendiagrys, 2015) yang menyatakan bahwa jika orang field independence dan field independence menggunakan proses kognitif yang berbeda, efektif kinerja mereka akan bervariasi dalam kondisi yang berbeda. Dalam penyelesaian soal, mereka menggunakan factor internal dimana istilah yang digunakan dituangkan ke dalam bahasa sendiri namun tidak sesuai dengan aturan. Hal ini senada dengan Morgan (Vendiagrys, 2015) yang percaya bahwa ketika bidangnya tidak diorganisir secara jelas, individu field independence relative cenderung menerapkan struktur mereka sendiri. Sesuai dengan karakteristik subjek field independence menurut Witkin, et. Al (Vendiagrys, 2015) bahwa mereka secara internal menunjukkan dan memproses informasi dengan strukturnya sendiri. 
Disamping itu, subjek field independence cenderung dapat menentukan hubungan antara variable dan membuat kesimpulan yang valid dari informasi yang diberikan. Sejalan dengan yang ditemukan bahwa individu field independence mengadopsi pendekatan impersoanal untuk penyelesaian soal, sedangkan individu field independence mengadopsi pendekatan interpersonal untuk menyelsaikan soal.

Dari hasil analisis jawaban dan wawancara diperoleh bahwa apa yang dilakukan oleh subjek field independence untuk menyelesaiakan soal adalah gaya kognitif field independence sudah mampu melihat aturan pada tipe soal sehingga mereka bisa menyelesaikan langkah yang harus diambil dengan bentuk tipe soal. Sehingga dalam mengerjakan soal subjek field independence memiliki alternative metode dengan memperhatikan syarat-syarat persepsinya.

Hal tersebut memberi gambaran bahwa subjek gaya kognitif field independence dapat memilah penggunaan metode dalam menentukan penyelesaian dari soal yang diberikan. Berdasarkan pendapat (Desmita, 2014) bahwa individu dengan gaya kognitif field independence lebih menunjukkan bagian-bagian terpisah dari pola menyeluruh dan mampu menganalisis pola ke dalam komponen-komponennya. Sehingga, subjek field independence tersebut memilih penggunaan metode-metode yang dikuasinya.

\section{KESIMPULAN}

Pemahaman siswa field dependence masih berada pada tahap Objek karena siswa belum dapat mengungkapkan pemahaman pengetahuan mengenai fungsi kuadrat dan fungsi rasional dengan cukup baik. Sedangkan pemahaman siswa field Independence verada pada tahap Skema. Gaya kognitif yang diterapkan oleh siswa field dependence adalah melihat soal kemudian mempersepsi metode sesuai dengan pengalaman yang pernah ditemui dan cenderung mengaplikasikan metode penyelesaian tidak bersumber dari pikirannya, hanya menerima pola yang sudah diajarkan oleh guru serta cenderung mengalami kesulitan fakta dikarenakan melakukan kesalahan dalam menuliskan notasi. Sedangkan siswa field independence adalah melihat soal kemudian memahami tipe-tipe soal dan memiliki alasan menggunakan suatu metode dalam menyelesaikan soal fungsi kuadrat dan fungsi rasional serta cenderung menggunakan faktor internal dimana istilah yang digunakan dituangkan ke dalam bahasa sendiri namun tidak sesuai dengan aturan.

\section{UCAPAN TERIMA KASIH}

Peneliti mengucapkan syukur kepada Allah SWT karena telah diberikan kelancaran menyelesaikan artikel ini. Kemudian berterima kasih juga kepada orang tua Bapak Khairizal, M.Pd dan Ibu Dra. Kurnia Erna yang telah memberikan dukungan selalu. Terima kasih kepada dosen pembimbing Bapak Prof. Drs. Damris M, M.Sc., Ph.D dan Bapak Dr. Drs. Kamid, M.Si yang telah memberikan arahan dan masukan sampai artikel ini selesai.

\section{REFERENSI}

Darmono, A. (2012). Identifikasi Gaya Kognitif (Cognitive Style) Peserta Didik dalam Belajar. Al-Mabsut. Desmita. (2010). Psikologi Perkembangan Cetakan Ke-IV. Bandung: PT. Remaja Rosdakarya Offset. https://doi.org/10.1017/CBO9781107415324.004 
Dubinsky, E., \& Mcdonald, M. A. (2005). APOS: A Constructivist Theory of Learning in Undergraduate Mathematics Education Research. In The Teaching and Learning of Mathematics at University Level. https://doi.org/10.1007/0-306-47231-7_25

Gusman, A., Kamid, K., \& Syamsurizal, S. (2018). Pengembangan Media Pembelajaran Interaktif Berdasarkan Teori Apos pada Materi Fungsi Kuadrat. Edu-Sains: Jurnal Pendidikan Matematika Dan Ilmu Pengetahuan Alam. https://doi.org/10.22437/jmpmipa.v6i1.5639

Hendriana, H., \& Sumarmo, U. (2017). Penilaian Pembelajaran Matematika. In PT Refika Aditama.

Khairani, N. (2008). Pembelajaran Matematika Menggunakan Teori Apos di Perguruan Tinggi. PARADIKMA, 01(01), 47-55.

Nila, K. (2008). Pemahaman konsep matematik dalam pembelajaran matematika. Prosiding SeminarNasional Matematika Dan Pendidikan Matematika, Jurusan Pendidikan Matematika Fakultas Matematika Dan Ilmu Pengetahuan Alam Universitas Negeri Yogyakarta.

Novitasari, D. (2016). Pengaruh Penggunaan Multimedia Interaktif Terhadap Kemampuan Pemahaman Konsep Matematis Siswa. FIBONACCI: Jurnal Pendidikan Matematika Dan Matematika, 2(2), 8. https://doi.org/10.24853/fbc.2.2.8-18

Strauss, A., \& Corbin, J. (2003). Penelitian Kualitatif. In Pustaka Pelajar. Yogyakarta.

Suriyah, P., \& Noeruddin, A. (2019). Efektivitas guided discovery learning dengan involving students in self and peer evaluation terhadap hasil belajar mahasiswa pada mata kuliah matematika diskrit. Jurnal Math Educator Nusantara: Wahana Publikasi Karya Tulis Ilmiah Di Bidang Pendidikan Matematika. https://doi.org/10.29407/jmen.v5i2.13515

Suryopurnomo, \& Pujiadi. (2017). Modul Pengembangan Keprofesionalan Berkelanjutan Guru SMA. Jakarta: Dirjen GTK Kemendikbud. 